\title{
An Empirical Study on the Cost of Institutional Boundaries and Lacking Financial Sophistication in the Mutual Fund Selection Process
}

\begin{abstract}
:
This paper contributes to the growing body of literature on private investors " investment mistakes in household finance. This paper takes off from the point that investors abstain from chasing alphas in selecting mutual funds, although Gruber (1996) has proven this to be a profitable strategy. He argues that reasons for this behaviour might be lack of investors' sophistication and/or institutional boundaries. Based on a survivorship bias free database of almost 3,000 mutual funds in 6 peer groups, this paper presents two main findings. Firstly, the difference between a sophisticated investor who chases past alpha performance and an unsophisticated investor who chooses a fund randomly is $2.9 \%$ p.a. expressed in alpha in the absence of institutional boundaries and $1.3 \%$ p.a. in their presence. Costs of institutional boundaries are only of economic relevance for sophisticated investors. In that case, the alpha performance is about $1.6 \%$ p.a. larger than in the presence of institutional boundaries. Secondly, we show that applying the newly proposed "Alpha Persistence Ratio" (APR) increases the annual alpha by 0.9\% compared to an institutionally unbounded alpha chasing strategy.
\end{abstract}

JEL classification: G11, G23

Keywords: Cost of investment mistakes, Mutual Funds, Fund performance, Fund selection criterion 


\section{Introduction}

Research in the area of household finance has produced plenty of evidence that households make investment mistakes. For instance, individual investors do not participate in the stock market at all (Guiso et al. (2003)), are under diversified (Calvet et al. (2007)), trade too much (Barber and Odean (2000)), or overweight domestic equity in their portfolios (Lewis (1999)).

With respect to mutual fund investments, research has documented so far that individual investors tend to put their money into actively managed mutual funds that usually do not outperform their respective benchmark indices (Malkiel (2003)). However, Gruber (1996) and Elton et al. (1996) provide evidence that there exists persistency in mutual fund performance. Recently, Kosowski et al. (2006) show that superior mutual fund performance and persistency is not driven by chance but by superior management ability and skill. If mutual fund performance is persistent, then every investor may generate above average returns, by purchasing those fund(s) with the highest past performance.

Empirical studies prove for the US American mutual fund market that investors indeed chase past performance, as funds with a superior past performance receive more cash inflows (Gruber (1996)). On the other hand, Gruber (1996) also points out that not much money is withdrawn from underperforming funds. In some cases under performing funds even receive net cash inflows. As an explanation, Gruber (1996) proposes that investors lack the financial sophistication and/or suffer from institutional boundaries (are constrained) which prevents them from chasing past performance.

The presence of both limitations for German individual investors can also be suspected for two reasons: Firstly, the financial knowledge of German investors seems to be rather low as studies which aim at measuring the financial literacy of German investors reveal for example that $50 \%$ are unable to differentiate between stocks and bonds (OECD (2005)). Secondly, institutional boundaries exist as particularly German banks cooperate intensively with their affiliated investment companies. This conjecture is supported by Ber et al. (2007) who also show for German investors that a substantial number of investors abstains from chasing performance. In fact, German investors even seem to chase less extensively than US investors (Sirri and Tufano (1998) and Ber et al. (2007)).

This paper contributes to the growing body of literature that seeks to determine the costs of the investment mistakes households make (e.g. Calvet et al. (2007)). Therefore, our 
first research objective is to calculate the costs of lacking financial sophistication and of being institutionally bound in the fund selection process. To the best of our knowledge no paper has yet aimed at quantifying these costs.

As a second research objective, this paper also seeks to contribute to the ongoing discussion on indicators and ratios that shall optimize the fund selection process. Recently, Cremers and Petajisto (2007) proposed a new measure based on the degree of active fund management to predict fund performance. We add to this strand of literature by proposing and testing another new fund selection criterion, which we call "Alpha Persistence Ratio" (APR). It includes explicitly a fund manager's ability to repeatedly generate superior performance.

We test our hypotheses based on a survivorship bias free sample of almost 3,000 actively managed mutual funds eligible for sale to German investors that is split into 6 mutually exclusive peer groups. Performance data for these funds covers 11 years of weekly return observations. For every fund it was verified if it belonged to an investment company affiliated to one of the six retail banks dominating the German market.

Regarding our first research objective, we find that a suboptimal fund selection process leads to non-trivial costs. In particular, the difference between a sophisticated investor who chases past Alpha performance and an unsophisticated investor who chooses a fund randomly is $2.9 \%$ p.a. expressed in Alpha in the absence of institutional boundaries and $1.3 \%$ p.a. in their presence. Costs of institutional boundaries are only of economic relevance for sophisticated investors. In that case, the Alpha performance is about $1.6 \%$ p.a. larger than in the presence of institutional boundaries. Regarding our second research objective, we show that applying the proposed "Alpha Persistence Ratio" (APR) increases the annual Alpha by $0.9 \%$ compared to an institutionally unbounded Alpha chasing strategy.

The structure of the paper is as follows. In section 2, we present the state of current research in the field of mutual funds and derive testable hypotheses. Section 3 describes the dataset and its composition. Section 4 deals with methodological issues. The empirical results on the costs of not chasing Alphas and of institutional boundaries as well as the performance of the "Alpha Persistence Ratio" are presented in section 5. In section 6 , we describe the results of additional robustness tests, and finally, section 7 concludes. 


\section{Literature Review and Hypotheses}

The current paper is based on a wide array of existing literature on mutual fund performance and on the relationship between fund performance and their respective cash flows.

As a prerequisite for the existence of the costs of lacking financial sophistication and institutional boundaries, it is an imperative that persistency of mutual fund performance is present. Based on the existing evidence, performance persistence in the mutual fund industry seems to be present. First empirical evidence goes back to Grinblatt and Titman (1992) who find that performance differences between funds persist over time. Elton et al. (1996) confirm these results applying risk-adjusted measures. Despite interim controversial discussion (e.g. Carhart (1997) in response to Hendricks et al. (1993)), subsequent studies again underline the notion of performance persistence among mutual funds (e.g. Hsiu-Lang et al. (2000)), Wermers (2000)). Recently, Kosowski et al. (2006) using a bootstrap analysis provide evidence that those fund managers who generate superior Alphas are not simply lucky, but, in fact skilled. For a more extensive literature overview on performance persistence please refer to Anderson and Schnusenberg (2005).

Given the existing evidence in support of persistence in mutual fund performance we hypothesize:

H1: Sophisticated German investors pursuing an Alpha-chasing strategy generate higher (risk-adjusted) returns than unsophisticated German investors who choose funds randomly.

Even though Alpha chasing pays for US investors, Gruber (1996) and more recently Keswani and Stolin (2008) observe by analyzing cash flows to mutual funds, that a nontrivial number of investors actually abstains from purchasing the fund(s) with highest past performance. Apart from lacking financial sophistication, Gruber (1996) provides a second plausible explanation: he argues that institutional boundaries might hinder investors from actually chasing past performance.

In Germany these institutional boundaries are presumably even more pronounced than in the US. It has been shown that financial advice exerts a decisive influence on household investment decisions (Zhao (2005), Jansen et al. (2008)). In Germany, more than 80 per cent of individual investors rely on financial advice when making an investment decision (DABbank (2004)). This advice is usually given by a non- 
independent financial advisor that is employed by a retail bank. Given the existing information asymmetry between financial advisors and clients, it is reasonable to assume that it is exploited by advisors (Ottaviani (2000)) who will then use their advantage to predominantly sell mutual funds offered by their employer's affiliated investment companies. The notion of more pronounced institutional boundaries in Germany is supported by a study of Ber et al. (2007) who point out that the connection between past performance and cash flows is much weaker in Germany than in the US. Additionally, they document a cannibalization effect between funds of a particular investment company that belong to the same peer group, which indicates that these funds compete for the same investors.

Of course, institutional boundaries limit the number of funds from which an investor can choose. Consequently, it may be possible that an investor is unable to choose some of the very best funds, simply because they are offered by another investment company. Moreover, it might also be sensible to assume that the average of a particular investment company is hence lower than the one of the entire fund universe. Following this line of argument directly leads to hypothesis two:

H2: The absence of institutional boundaries leads to on average higher (riskadjusted) returns for all types of investors.

Even by pursing an Alpha chasing strategy, empirical studies show that it is difficult to outperform the respective benchmark or comparable index funds, at least on a net of cost basis (Elton et al. (1996), Gruber (1996), Frino and Gallagher (2001)). In the light of these studies, a discussion on enhanced mutual fund selection strategies and indicators, that might allow outperforming a benchmark, has evolved.

Bliss and Potter (2002) as well as Niessen and Ruenzi (2006) focus on gender specific investment styles for fund managers. However, they are unable to prove these styles to result in exploitable performance differences. On the other hand, Chan et al. (2002) find performance differences depending on a fund's investment styles. Additionally, they argue that an approach relying on fund portfolio characteristics allows better predicting future returns. Recently, this discussion has been enriched by Cremers and Petajisto (2007) who introduce an alternative evaluation measure combining the tracking error of a fund and the degree to which a fund's asset allocation deviates from the benchmark (active share). They find that deploying the active share criterion results in a significant outperformance of the respective benchmark indices. 
Whereas their approach requires a lot of data on the positions each mutual fund holds, we contribute to the ongoing discussion by proposing a new measure which we call "Alpha Persistence Ratio" (APR) that only requires past return data. This measure is based on the idea that a fund manager needs to generate a high Alpha not only once but repeatedly. We expect that including further easily available information on the persistency of a mutual fund's performance in relation to its peers might further enhance the outcomes of a sophisticated fund selection strategy. Consequently, our third hypothesis can be formulated:

H3: Using the "Alpha Persistence Ratio" (APR) as fund selection criterion enhances the performance compared to the Alpha-chasing-strategy.

\section{Data}

In recent years there have been many studies concerning the mutual fund industry. One major prerequisite for a profound analysis is a survivorship-bias free and extensive database. As Elton et al. (2001) state, missing data points as well as an existing survivorship bias can distort performance analysis of mutual funds, since terminated funds usually underperform significantly. Still, these errors are common in any database that only mirrors the current available fund range, since terminated or merged mutual funds are not considered.

To create a survivorship bias free sample of the German mutual fund market we use the Morningstar database that has been proven to be of high quality in studies on the American mutual fund market. (see Elton et al. (2001)). We concentrate on funds licensed for sale to German investors. Since Morningstar data is only available from 2002 to 2006, we supplement our database with funds that had existed previously. Information on these funds has been provided by two German suppliers, namely Hoppenstedt and VWD. The final sample period ranges from 1994 to 2006 which includes several up- and downturns in stock markets. Weekly mutual fund return data was obtained from Thomson Financial Datastream and is dividend adjusted and net of fees, but does not include any form of loads.

The actual period for investor decision making and fund performance calculation ranges from 1994 to 2005 . Funds that started later than 1994 could only be considered after 12 or 24 months of existence, depending on the actual performance measure used (see next section for details). This restriction should not affect the results of this paper, since Carhart et al. (2002) and Kosowski et al. (2006) show that short-lived funds do not have 
substantially and significantly different average returns than longer-lived funds.

To assure the comparability of risk-adjusted performance of funds, we compile several peer groups. These peer groups are based on the respective geographical investment objective stated in the databases. For our study, we assemble 6 peer groups. Four of them consist of equity mutual funds (Germany Blue Chips, Europe Blue Chips, North America Blue Chips and Asia Blue Chips), whereas two include bond mutual funds (US Dollar and EURO). The four equity peer groups were chosen, as these regions capture more than $80 \%$ the world stock market capitalization and the two bond peer groups represent the world's leading currencies. Additionally, in each peer group, there are enough funds to test our three hypotheses.

To analyze the effects of institutional boundaries, we identified the respective investment company managing a particular fund. This analysis concentrates on the six largest investment companies in Germany all affiliated to one of the six dominating banks or bank groups. The six investment companies considered are Deka (savings banks), Union (cooperative banks), DWS (Deutsche Bank), AGI (Dresdner Bank/ Allianz Group), Cominvest (Commerzbank) and Pioneer (Hypo-Vereinsbank/ Unicredit).

\section{Table 1: Market Share of Investment Companies in Germany}

The figure shows the number and the volume of the funds managed by the six dominating investment companies on the German market in 09/2007. The figure includes all publicly traded mutual funds that are licensed for sale to individual German private investors (BVI (2007)).

\begin{tabular}{|c|c|c|c|c|}
\hline \multirow[b]{2}{*}{ Source } & \multicolumn{2}{|c|}{ Volume of public funds } & \multicolumn{2}{|c|}{ Number of public funds } \\
\hline & million Euro & $\%$ & \# & $\%$ \\
\hline Investment companies & 494,010 & $75.7 \%$ & 2,584 & $51.8 \%$ \\
\hline$D W S$ & 142,520 & $21.9 \%$ & 666 & $13.4 \%$ \\
\hline Deka & 129,448 & $19.8 \%$ & 579 & $11.6 \%$ \\
\hline Union & 95,927 & $14.7 \%$ & 274 & $5.5 \%$ \\
\hline AGI / dit & 72,577 & $11.1 \%$ & 451 & $9.0 \%$ \\
\hline Cominvest & 27,784 & $4.3 \%$ & 314 & $6.3 \%$ \\
\hline Pioneer & 25,754 & $3.9 \%$ & 300 & $6.0 \%$ \\
\hline Other Source Funds & 158,156 & $24.3 \%$ & 2,400 & $48.2 \%$ \\
\hline Overall & 652,166 & $100.0 \%$ & 4,984 & $100.0 \%$ \\
\hline
\end{tabular}

Table 1 shows that the six investment companies account for more than $75 \%$ of the mutual fund holdings of German investors. All funds that cannot be assigned to one of these six investment companies are classified as "other source funds". 
The database finally contains 2,936 (both survived and non-survived) mutual funds. The largest peer group is Stocks Europe Blue Chips with 908 funds, the smallest Stocks Germany Blue Chips containing 188 funds. The number of available funds per investment company ranges from 51 to 121 funds. However, for a few peer groups some of the investment companies only offer a very limited number of funds. An overview of the number of funds in total and per investment company is provided in Table 2.

\section{Table 2: Number of Funds in Database}

The table summarizes the funds in the database. It reports the number of mutual funds during the 1994 to 2005 period for each of the six peer groups analyzed in this study. Additionally, the table depicts the number of funds that are managed by one of the dominating six investment companies.

\begin{tabular}{|c|c|c|c|c|c|c|c|c|c|}
\hline \multirow[b]{3}{*}{ No. } & \multirow[b]{3}{*}{ Peer group } & \multirow{2}{*}{\multicolumn{6}{|c|}{ Investment Company }} & \multirow{3}{*}{$\begin{array}{l}\text { Other Source } \\
\text { Funds }\end{array}$} & \multirow{3}{*}{$\begin{array}{c}\text { Overall } \\
\text { (Unconstrained } \\
\text { investor) }\end{array}$} \\
\hline & & & & & & & & & \\
\hline & & DWS & Deka & Union & AGI / dit & Cominvest & Pioneer & & \\
\hline 1 & Stocks Germany Blue Chips & 13 & 8 & 11 & 7 & 15 & 5 & 129 & 188 \\
\hline 2 & Stocks Europe Blue Chips & 29 & 18 & 23 & 29 & 23 & 48 & 738 & 908 \\
\hline 3 & Stocks North America Blue Chips & 4 & 1 & 6 & 11 & 11 & 24 & 585 & 642 \\
\hline 4 & Stocks Asia Blue Chips & 3 & 0 & 4 & 13 & 3 & 8 & 280 & 311 \\
\hline 5 & Bonds EURO & 28 & 23 & 25 & 28 & 23 & 30 & 476 & 633 \\
\hline 6 & Bonds USD & 4 & 1 & 2 & 2 & 2 & 6 & 237 & 254 \\
\hline \multicolumn{2}{|l|}{ Sum } & 81 & 51 & 71 & 90 & 77 & 121 & 2,445 & 2,936 \\
\hline
\end{tabular}

\section{Model and Methodology}

Our fund selection and evaluation procedure is based on Jensen's Alpha (Jensen (1968)). Recent studies have shown that results do not change once more sophisticated Alpha estimation techniques are used (Carhart (1997), Gruber (1996) and Kosowski et al. (2006)). The formula for the one-factor model is as follows

$$
r_{i}-r_{f}=\widehat{\alpha}_{i}+\beta_{i}\left(r_{m}-r_{f}\right)+\varepsilon_{i}
$$

where $r_{i}$, is the return of fund $i, r_{f}$ is the return on a three month cash position, $r_{m}$ is the return of a peer group's benchmark index, $\beta_{\mathrm{i}}$ is the sensitivity of fund $i$ to the return on the benchmark index, $\alpha_{\mathrm{i}}$ is the risk-adjusted return on fund $\mathrm{i}$ and $\varepsilon_{\mathrm{i}}$ is the error term.

For all performance evaluations we model that an investor invests every week in one fund and holds that fund for one year. Therefore, in this study we distinguish two time periods. In the first (estimation period) the Alpha is computed based on a full year of 52 weeks as a starting point for the fund selection process. Then, over the following 52 weeks (performance period) we measure the fund's performance to evaluate a particular selection strategy. By using a rolling-window approach, we can assemble a total of 574 investor decision points.

Our database documents if a fund is not available to the investor anymore. These funds could be closed or merged with another fund. However, we cannot determine whether 
funds were closed or merged and, - in case of a merger - the target fund. Thus we assume that our investor can not invest in funds that vanish over the one year holding period. Implications of this approach on the validity of our results will be discussed in section 5 .

To test the hypotheses brought up in section 2, this paper follows a stepwise approach. As Figure 1 shows, in a first step this paper aims to analyze whether a sophisticated Alpha- chasing strategy actually pays-off, then in a second step the target is to determine the effects of institutional boundaries on investment returns for both institutionally bounded (contrained) and institutionally unbounded (unconstrained) investors. In the final step, this paper investigates the question if an enhanced fund selection criterion may further improve the returns to a sophisticated investor.

\section{Figure 1: Overview of Investor Types and Strategies}

The figure summarizes the steps in which the study discusses the hypotheses outlined in section 2.

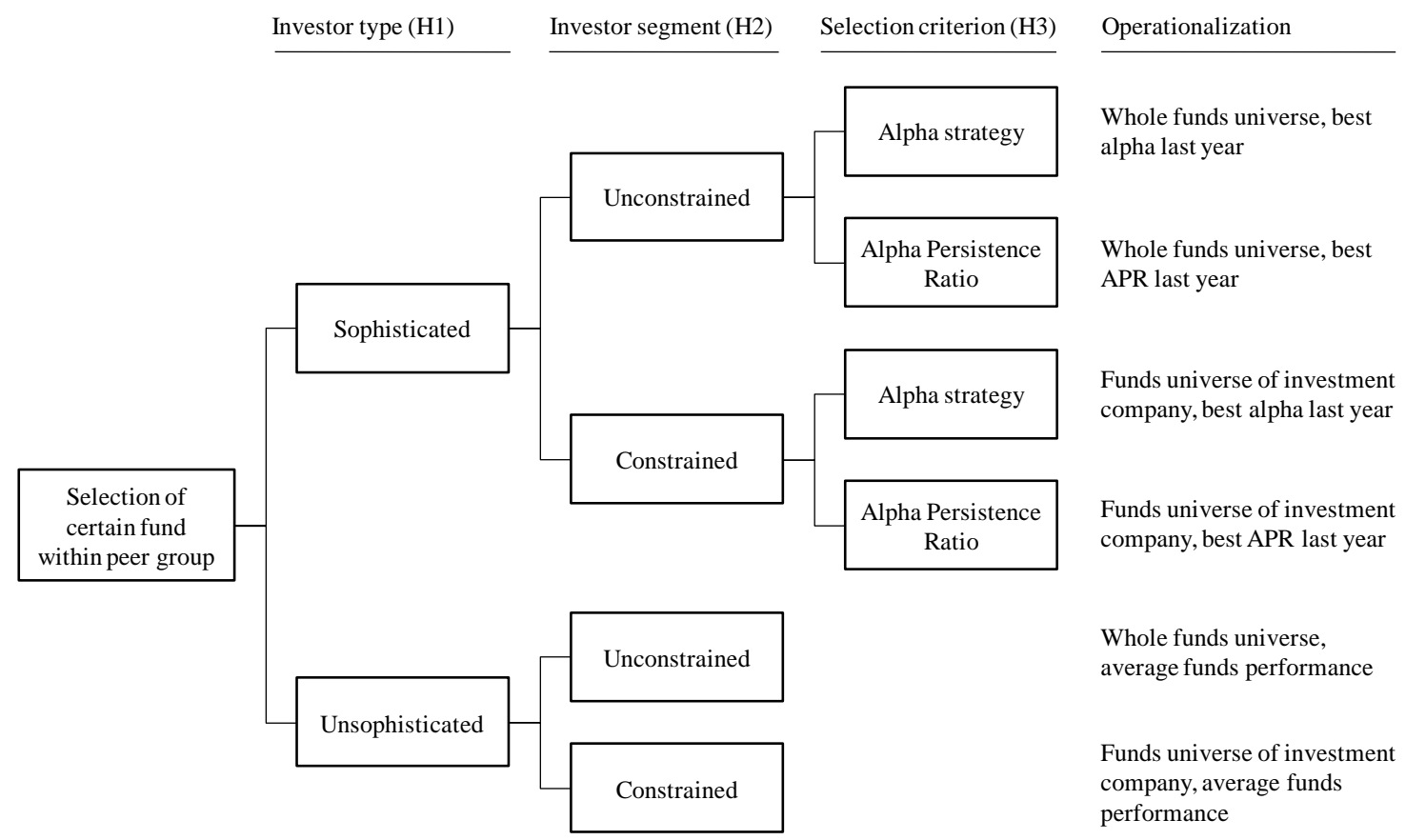

To test whether Alpha- chasing is a profitable strategy, we differentiate between two different types of investors. The first is a sophisticated investor who possesses a high financial ability and is hence able to invest based on an informed basis and pursue an Alpha chasing strategy. Therefore, in a respective peer group a sophisticated investor selects the fund out of the fund universe available with the highest Alpha in the 52 weeks prior to the investment decision. The second one is an unsophisticated investor who chooses a fund randomly out of a peer group. To compute the performance of the 
unsophisticated investor, this paper uses the non-weighted average performance of a peer group's fund universe over the performance period. This is reasonable since repeated random draws of single funds and then averaging the performances of these random draws, would necessarily approach the average of a peer group's fund universe.

To test whether institutional boundaries are costly to an individual investor, we create two additional investor segments. In the first segment the investor is unconstrained and can choose among all the funds licensed for sale in Germany in a particular peer group without any restrictions. The second investor segment represents investors who are constrained to one of the six major investment companies. In this case, investors can only select a fund out of the range of a specific investment company in a certain peer group.

Potential costs of these institutional boundaries are then computed for sophisticated and unsophisticated investors. This allows us to contrast sophisticated but constrained investors, with their unconstrained counterpart. Additionally, the same procedure can be applied to unsophisticated investors.

Having tested hypothesis 1 and 2, we can also determine and compare the costs of not pursuing an Alpha-chasing strategy (i.e. being unsophisticated) and the costs of institutional boundaries. According to our hypotheses the utmost costs to an investor should arise when the investor is simultaneously unsophisticated and institutionally bounded.

As already outlined in the derivation of the third hypothesis this paper proposes a new fund selection criterion which we call "Alpha Persistence Ratio" (APR). We compute the APR by dividing the annual Jensen's Alpha by the standard deviation of the Alphadeciles of that fund for the year prior to the investment date. This measure is based on the conjecture that a fund manager needs to generate a high Alpha which is represented by the nominator; and also needs to be able to repeat this superior performance regularly which is measured by the standard deviation in the denominator. The APR is defined by formula (2).

$$
\text { Alpha Persistence Ratio }=\frac{\alpha_{\mathrm{i}, \mathrm{t}-1 \rightarrow \mathrm{t}}}{\sigma_{\operatorname{Decile}\left(\alpha_{\mathrm{it}}\right)}}
$$

Where $\alpha_{i, t-1 \rightarrow t}$ is the risk-adjusted performance of fund $i$ in the one year period prior to the investment date, and $\sigma_{\operatorname{Decile}\left(\alpha_{i t}\right)}$ represents the standard deviation of Alpha-deciles which is also calculated based on the prior year. In order to compute this standard 
deviation fund performance data of one additional year has to be used. Alpha deciles are calculated relative to all funds of a particular peer group for a particular date.

The rationale for using standard deviation of Alpha deciles instead of the standard deviation of Alphas directly is that the latter would strongly depend on market movements. In the instance of high market volatility, the direct usage of standard deviations would distort the results, whereas using the standard deviation of Alpha deciles, measures the performance of funds relative to the performance of funds from a respective peer group, which is independent of market movements.

Unfortunately, there is one potential drawback of the APR. If there is no fund within a peer group exhibiting a positive Alpha, there is an inverse effect of the standard deviation. In that case a higher standard deviation would bias the APR upwards. Consequently, any decision based on this measure would be incorrect. However, the effect of this inverse reaction should be negligible if a peer group's fund universe is big enough as there usually exists at least one fund with a positive Alpha. In order to assess the severity of this drawback, we carefully inspected all peer groups and found that there is not a single time period in any peer group, where only funds with negative Alphas exist. Hence, this drawback does not affect our results in any way.

In order to test our hypothesis we employ three different measures in the performance period. Firstly, analogous to the fund selection strategy, this paper uses the Jensen's Alpha to estimate the risk-adjusted one year performance of the selected funds. Secondly, we compute and compare one year buy-and-hold returns and finally, an outperformance ratio is employed which indicates the frequency in which a particular fund outperformed its benchmark index. The outperformance ratio can be understood as percentage figure ranging from $0 \%$ (never outperformed benchmark) to $100 \%$ (always outperformed benchmark) and is calculated as follows

$$
\text { Outperformance ratio }=\frac{\sum_{\mathrm{t}=1}^{\mathrm{T}} \mathrm{II}_{\left\{\mathrm{r}_{\mathrm{i}, \mathrm{t}}>\mathrm{r}_{\mathrm{m}, \mathrm{t}}\right\}}}{\mathrm{T}}, \quad \mathrm{II}_{\left\{\mathrm{r}_{\mathrm{i}, \mathrm{t}}>\mathrm{r}_{\mathrm{m}, \mathrm{t}}\right\}}:=\left\{\begin{array}{l}
1, \mathrm{r}_{\mathrm{i}, \mathrm{t}}>\mathrm{r}_{\mathrm{m}, \mathrm{t}} \\
0, \text { else }
\end{array}\right.
$$

Where II is one if the fund outperforms the benchmark index and zero otherwise, and T is number of observations. The following section presents descriptive statistics and discusses results with respect to our hypotheses. 


\section{$5 \quad$ Results and Discussion}

Table 3 presents descriptive statistics of the performance of the mutual funds in our sample. Over the whole sample period the funds generate on average a negative Alpha of $-0.97 \%$ p.a. with only two peer groups exhibiting a positive average Alpha. The average return of all funds in the sample period was only $5.12 \%$ p.a., whereas the respective benchmark indices yielded an average of $8.21 \%$ p.a.. These numbers are in line with previous studies on mutual fund performance, which usually document an underperformance of the average actively managed mutual fund (See e.g. Malkiel (2003)).

\section{Table 3: Descriptive Statistics of Fund Performance}

The table reports time-series averages of mutual funds split by peer group or investment company from 1995 to 2005 . Alpha is the intercept in the regression of the excess fund return against the excess return on the respective benchmark index. Return is the one year buy-andhold return, whereas Benchmark refers to the one-year buy-and-hold return of the respective benchmark index. Difference is the return on the fund minus the return on the respective benchmark index. All figures are annualized. \# of funds includes alive and dead funds.

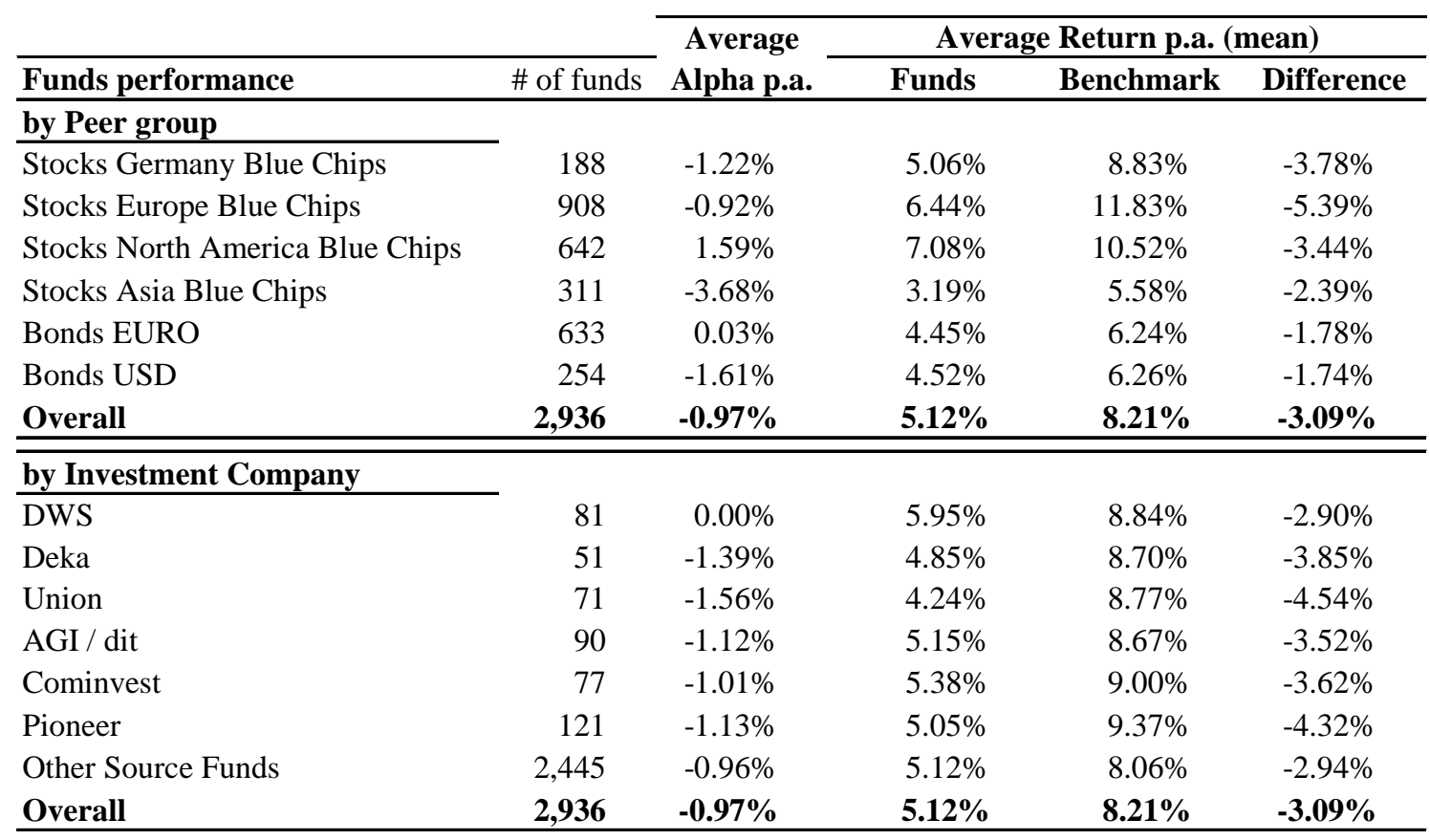

With respect to the performance of investment companies only DWS funds achieve a non-negative average Alpha. Expressed as one year buy-and-hold returns, all investment companies on average underperform their benchmarks. Compared to the funds of the six investment companies, mutual funds from other providers do not perform differently.

In order to deepen our analysis, we now turn to hypothesis one, recalling that hypothesis one states that a sophisticated investor who chases Alphas outperforms their unsophisticated counterpart who selects a fund randomly. 
As a prerequisite for our first hypothesis to be true, it is necessary that persistency in the performance of German mutual funds is discernible. As described in section 4, we use a Jensen's Alpha model to evaluate fund performance. In determining the performance persistence we follow the approach outlined by Gruber (1996) by grouping funds into deciles according to their Alpha and then observe average performance of funds from a particular decile over the following year. The results are summarized in Table 4. It becomes obvious that performance persistence among German mutual funds does exist.

\section{Table 4: Performance Persistence using Jensen's Alpha}

In each of the panels mutual funds are sorted each week into deciles based on their unconditional Jensen's Alpha estimated over the prior 52 weeks. Funds with missing observations are excluded. The portfolios are equally weighted, thus the weights are adjusted once a new fund appears or disappears. Decile 10 comprises Funds with highest one year Alpha, while funds with the lowest Alpha are summarized in decile 1. The top fund is the fund with highest Alpha over the estimation period. The last two rows represent the difference in Alphas between the top fund and the top decile as well as between the top fund and the bottom decile. The last two columns report p-values of parametric t-tests and non-parametric Wilcoxon tests.

\begin{tabular}{|c|c|c|c|c|c|c|c|}
\hline \multicolumn{8}{|c|}{ Panel A: Peergroup Germany Blue Chips } \\
\hline Fractile & Obs. & Mean & Std. Dev. & Min & Max & $\begin{array}{l}\text { One tailed p- } \\
\text { Value }\end{array}$ & Rank test \\
\hline Decile 1 (worst) & 574 & $-1.80 \%$ & $6.73 \%$ & $-24.38 \%$ & $12.60 \%$ & 0.00 & 0.00 \\
\hline Decile 2 & 574 & $-1.45 \%$ & $5.76 \%$ & $-26.20 \%$ & $14.55 \%$ & 0.00 & 0.00 \\
\hline Decile 3 & 574 & $-0.87 \%$ & $5.37 \%$ & $-26.24 \%$ & $19.40 \%$ & 0.00 & 0.01 \\
\hline Decile 4 & 574 & $-0.86 \%$ & $4.82 \%$ & $-24.76 \%$ & $15.40 \%$ & 0.00 & 0.00 \\
\hline Decile 5 & 574 & $-0.84 \%$ & $4.61 \%$ & $-23.18 \%$ & $12.28 \%$ & 0.00 & 0.00 \\
\hline Decile 6 & 574 & $-0.65 \%$ & $4.66 \%$ & $-27.17 \%$ & $13.69 \%$ & 0.00 & 0.05 \\
\hline Decile 7 & 574 & $-0.80 \%$ & $4.88 \%$ & $-25.42 \%$ & $14.29 \%$ & 0.00 & 0.01 \\
\hline Decile 8 & 574 & $-0.52 \%$ & $5.25 \%$ & $-21.80 \%$ & $13.73 \%$ & 0.01 & 0.69 \\
\hline Decile 9 & 574 & $-0.19 \%$ & $6.08 \%$ & $-24.08 \%$ & $12.00 \%$ & 0.23 & 0.00 \\
\hline Decile 10 (best) & 574 & $0.53 \%$ & $8.83 \%$ & $-33.51 \%$ & $20.28 \%$ & 0.08 & 0.00 \\
\hline Top fund & 574 & $4.67 \%$ & $12.31 \%$ & $-30.56 \%$ & $41.40 \%$ & 0.00 & 0.00 \\
\hline Sprd. Top - 10 & 574 & $4.14 \%$ & $9.51 \%$ & & & 0.00 & 0.00 \\
\hline Sprd. Top - 1 & 574 & $6.47 \%$ & $10.90 \%$ & & & 0.00 & 0.00 \\
\hline \multicolumn{8}{|c|}{ Panel B: Peergroup Europe BC } \\
\hline Fractile & Obs. & Mean & Std. Dev. & Min & Max & $\begin{array}{l}\text { One tailed p- } \\
\text { Value }\end{array}$ & Rank test \\
\hline Decile 1 (worst) & 574 & $-0.63 \%$ & $15.93 \%$ & $-41.45 \%$ & $28.32 \%$ & 0.17 & 0.35 \\
\hline Decile 2 & 574 & $-0.22 \%$ & $12.81 \%$ & $-33.85 \%$ & $27.36 \%$ & 0.34 & 0.57 \\
\hline Decile 3 & 574 & $-0.05 \%$ & $12.43 \%$ & $-32.17 \%$ & $25.83 \%$ & 0.46 & 0.40 \\
\hline Decile 4 & 574 & $-0.06 \%$ & $12.49 \%$ & $-37.14 \%$ & $27.71 \%$ & 0.45 & 0.42 \\
\hline Decile 5 & 574 & $-0.33 \%$ & $12.68 \%$ & $-37.70 \%$ & $28.54 \%$ & 0.27 & 0.75 \\
\hline Decile 6 & 574 & $-0.01 \%$ & $13.18 \%$ & $-37.10 \%$ & $30.98 \%$ & 0.49 & 0.44 \\
\hline Decile 7 & 574 & $0.03 \%$ & $13.16 \%$ & $-35.70 \%$ & $30.63 \%$ & 0.48 & 0.36 \\
\hline Decile 8 & 574 & $0.35 \%$ & $13.25 \%$ & $-29.31 \%$ & $30.03 \%$ & 0.26 & 0.15 \\
\hline Decile 9 & 574 & $1.48 \%$ & $13.65 \%$ & $-30.52 \%$ & $31.54 \%$ & 0.00 & 0.00 \\
\hline Decile 10 (best) & 574 & $3.21 \%$ & $16.67 \%$ & $-50.38 \%$ & $36.51 \%$ & 0.00 & 0.00 \\
\hline Top fund & 574 & $4.36 \%$ & $29.42 \%$ & $-121.49 \%$ & $79.89 \%$ & 0.00 & 0.00 \\
\hline Sprd. Top - 10 & 574 & $1.12 \%$ & $19.40 \%$ & & & 0.08 & 0.00 \\
\hline Sprd. Top - 1 & 574 & $4.97 \%$ & $24.05 \%$ & & & 0.00 & 0.00 \\
\hline
\end{tabular}


Table 4 Cont.: Performance Persistence using Jensen's Alpha

\begin{tabular}{|c|c|c|c|c|c|c|c|}
\hline \multicolumn{8}{|c|}{ Panel C: Peergroup North America Blue Chips } \\
\hline Fractile & Obs. & Mean & Std. Dev. & Min & Max & $\begin{array}{l}\text { One tailed p- } \\
\text { Value }\end{array}$ & Rank test \\
\hline$\overline{\text { Decile } 1 \text { (worst) }}$ & 574 & $1.22 \%$ & $12.19 \%$ & $-30.73 \%$ & $37.10 \%$ & 0.01 & 0.09 \\
\hline Decile 2 & 574 & $1.14 \%$ & $10.58 \%$ & $-23.84 \%$ & $35.76 \%$ & 0.01 & 0.04 \\
\hline Decile 3 & 574 & $1.29 \%$ & $10.33 \%$ & $-23.50 \%$ & $36.60 \%$ & 0.00 & 0.03 \\
\hline Decile 4 & 574 & $1.32 \%$ & $10.31 \%$ & $-21.77 \%$ & $38.08 \%$ & 0.00 & 0.06 \\
\hline Decile 5 & 574 & $1.31 \%$ & $10.30 \%$ & $-21.40 \%$ & $38.42 \%$ & 0.00 & 0.10 \\
\hline Decile 6 & 574 & $1.41 \%$ & $10.22 \%$ & $-20.40 \%$ & $38.67 \%$ & 0.00 & 0.08 \\
\hline Decile 7 & 574 & $1.48 \%$ & $10.22 \%$ & $-20.09 \%$ & $40.02 \%$ & 0.00 & 0.08 \\
\hline Decile 8 & 574 & $1.58 \%$ & $10.20 \%$ & $-19.90 \%$ & $40.45 \%$ & 0.00 & 0.06 \\
\hline Decile 9 & 574 & $1.65 \%$ & $10.30 \%$ & $-19.51 \%$ & $40.98 \%$ & 0.00 & 0.06 \\
\hline Decile 10 (best) & 574 & $1.86 \%$ & $10.38 \%$ & $-21.05 \%$ & $40.67 \%$ & 0.00 & 0.03 \\
\hline Top fund & 574 & $2.99 \%$ & $23.04 \%$ & $-148.43 \%$ & $58.44 \%$ & 0.00 & 0.00 \\
\hline Sprd. Top - 10 & 574 & $1.13 \%$ & $20.70 \%$ & & & 0.10 & 0.00 \\
\hline Sprd. Top - 1 & 574 & $1.76 \%$ & $23.81 \%$ & & & 0.04 & 0.00 \\
\hline \multicolumn{8}{|c|}{ Panel D: Peergroup Asia BC } \\
\hline Fractile & Obs. & Mean & Std. Dev. & Min & Max & $\begin{array}{l}\text { One tailed p- } \\
\text { Value }\end{array}$ & Rank test \\
\hline Decile 1 (worst) & 574 & $-5.41 \%$ & $23.43 \%$ & $-97.82 \%$ & $58.94 \%$ & 0.00 & 0.00 \\
\hline Decile 2 & 574 & $-4.50 \%$ & $21.00 \%$ & $-76.04 \%$ & $52.82 \%$ & 0.00 & 0.00 \\
\hline Decile 3 & 574 & $-4.79 \%$ & $21.31 \%$ & $-88.73 \%$ & $54.43 \%$ & 0.00 & 0.00 \\
\hline Decile 4 & 574 & $-4.51 \%$ & $21.98 \%$ & $-86.81 \%$ & $61.22 \%$ & 0.00 & 0.00 \\
\hline Decile 5 & 574 & $-4.02 \%$ & $22.17 \%$ & $-87.90 \%$ & $61.18 \%$ & 0.00 & 0.00 \\
\hline Decile 6 & 574 & $-4.04 \%$ & $21.78 \%$ & $-91.05 \%$ & $60.35 \%$ & 0.00 & 0.00 \\
\hline Decile 7 & 574 & $-3.47 \%$ & $21.95 \%$ & $-91.47 \%$ & $61.38 \%$ & 0.00 & 0.00 \\
\hline Decile 8 & 574 & $-2.91 \%$ & $21.76 \%$ & $-84.59 \%$ & $59.54 \%$ & 0.00 & 0.00 \\
\hline Decile 9 & 574 & $-3.07 \%$ & $20.83 \%$ & $-80.64 \%$ & $53.78 \%$ & 0.00 & 0.00 \\
\hline Decile 10 (best) & 574 & $-3.30 \%$ & $19.70 \%$ & $-76.14 \%$ & $47.68 \%$ & 0.00 & 0.00 \\
\hline Top fund & 574 & $-3.12 \%$ & $22.04 \%$ & $-85.88 \%$ & $55.63 \%$ & 0.00 & 0.02 \\
\hline Sprd. Top - 10 & 574 & $0.19 \%$ & $13.41 \%$ & & & 0.37 & 0.05 \\
\hline Sprd. Top - 1 & 574 & $2.29 \%$ & $15.07 \%$ & & & 0.00 & 0.01 \\
\hline \multicolumn{8}{|c|}{ Panel E: Peergroup Bonds EURO } \\
\hline Fractile & Obs. & Mean & Std. Dev. & Min & Max & $\begin{array}{c}\text { One tailed p- } \\
\text { Value }\end{array}$ & Rank test \\
\hline$\overline{\text { Decile } 1 \text { (worst) }}$ & 574 & $-1.14 \%$ & $2.06 \%$ & $-5.87 \%$ & $6.51 \%$ & 0.00 & 0.00 \\
\hline Decile 2 & 574 & $-0.18 \%$ & $1.50 \%$ & $-4.13 \%$ & $6.94 \%$ & 0.00 & 0.00 \\
\hline Decile 3 & 574 & $-0.10 \%$ & $1.58 \%$ & $-5.71 \%$ & $7.37 \%$ & 0.06 & 0.08 \\
\hline Decile 4 & 574 & $0.17 \%$ & $1.69 \%$ & $-4.82 \%$ & $7.95 \%$ & 0.01 & 0.22 \\
\hline Decile 5 & 574 & $0.28 \%$ & $1.91 \%$ & $-6.10 \%$ & $8.13 \%$ & 0.00 & 0.02 \\
\hline Decile 6 & 574 & $0.30 \%$ & $1.94 \%$ & $-5.68 \%$ & $8.31 \%$ & 0.00 & 0.00 \\
\hline Decile 7 & 574 & $0.26 \%$ & $1.80 \%$ & $-4.29 \%$ & $9.64 \%$ & 0.00 & 0.00 \\
\hline Decile 8 & 574 & $0.33 \%$ & $1.73 \%$ & $-4.02 \%$ & $11.70 \%$ & 0.00 & 0.00 \\
\hline Decile 9 & 574 & $0.27 \%$ & $2.10 \%$ & $-6.98 \%$ & $8.12 \%$ & 0.00 & 0.00 \\
\hline Decile 10 (best) & 574 & $1.72 \%$ & $1.98 \%$ & $-4.24 \%$ & $8.42 \%$ & 0.00 & 0.00 \\
\hline Top fund & 574 & $2.40 \%$ & $9.82 \%$ & $-186.06 \%$ & $20.74 \%$ & 0.00 & 0.00 \\
\hline Sprd. Top - 10 & 574 & $0.59 \%$ & $9.54 \%$ & & & 0.07 & 0.00 \\
\hline Sprd. Top - 1 & 574 & $3.45 \%$ & $9.75 \%$ & & & 0.00 & 0.00 \\
\hline
\end{tabular}


Table 4 Cont. 2: Performance Persistence using Jensen's Alpha

\begin{tabular}{lrrrrrrr}
\hline \multicolumn{1}{c}{ Practile } & \multicolumn{7}{c}{ Panel F: Peergroup Bonds USD } \\
\hline Obs. & Mean & Std. Dev. & \multicolumn{1}{c}{ Min } & Max & $\begin{array}{c}\text { One tailed p- } \\
\text { Value }\end{array}$ & Rank test \\
\hline Decile 1 (worst) & 574 & $-4.11 \%$ & $5.67 \%$ & $-33.95 \%$ & $5.32 \%$ & 0.00 & 0.00 \\
Decile 2 & 574 & $-1.74 \%$ & $2.27 \%$ & $-10.67 \%$ & $4.28 \%$ & 0.00 & 0.00 \\
Decile 3 & 574 & $-1.14 \%$ & $1.84 \%$ & $-7.83 \%$ & $7.50 \%$ & 0.00 & 0.00 \\
Decile 4 & 574 & $-1.04 \%$ & $1.60 \%$ & $-6.66 \%$ & $8.25 \%$ & 0.00 & 0.00 \\
Decile 5 & 574 & $-0.81 \%$ & $1.93 \%$ & $-9.33 \%$ & $7.99 \%$ & 0.00 & 0.00 \\
Decile 6 & 574 & $-0.79 \%$ & $1.89 \%$ & $-8.45 \%$ & $8.76 \%$ & 0.00 & 0.00 \\
Decile 7 & 574 & $-0.83 \%$ & $1.91 \%$ & $-7.99 \%$ & $8.22 \%$ & 0.00 & 0.00 \\
Decile 8 & 574 & $-0.86 \%$ & $1.67 \%$ & $-6.33 \%$ & $9.01 \%$ & 0.00 & 0.00 \\
Decile 9 & 574 & $-0.72 \%$ & $1.77 \%$ & $-7.88 \%$ & $7.71 \%$ & 0.00 & 0.00 \\
Decile 10 (best) & 574 & $-0.08 \%$ & $2.27 \%$ & $-8.08 \%$ & $7.05 \%$ & 0.20 & 0.47 \\
Top fund & 574 & $0.02 \%$ & $6.80 \%$ & $-38.28 \%$ & $13.95 \%$ & 0.47 & 0.69 \\
Sprd. Top - 10 & 574 & $0.10 \%$ & $5.34 \%$ & & & 0.32 & 0.10 \\
Sprd. Top - 1 & 574 & $4.13 \%$ & $7.82 \%$ & & & 0.00 & 0.00 \\
\hline
\end{tabular}

The decile 1 includes the $10 \%$ of funds with the lowest prior Alpha performance whereas the decile 10 includes the $10 \%$ of funds with the highest prior Alpha performance. The mean represents the average one year Alpha of the respective decile over the following year. From the bottom decile to the top one, a clear positive trend is observable. Most of the Alphas are statistically significantly different from zero as t-test reveal. In order to account for potential non-normality in the Alpha distribution, we further conduct a non-parametric Wilcoxon test, which yields the same results as the ttest in the overwhelming majority of cases. The difference between the top fund and the lowest Alpha decile is always positive and statistically significant. In four out of the six peer groups the top fund outperforms the $10^{\text {th }}$ decile. The outperformance is at least statistically significant at the 10\%-level. Figure 2 illustrates the existing performance persistence among the mutual funds in the respective peer groups graphically.

On the horizontal axis, the Alpha decile over the estimation period is represented, and on the vertical axis the average annual Alpha of this decile's funds over the performance period is depicted. It becomes evident that strong performance persistence is existent. Consequently, an Alpha chasing strategy as proposed by Gruber (1996) may also be profitable in the German fund market. Hence, it seems likely that all unsophisticated investors not chasing Alphas will have to bear some costs. Therefore, in a next step, this paper aims at computing the costs of being unsophisticated. 


\section{Figure 2: Performance Persistence using Jensen's Alpha}

The figure illustrates the performance persistence in the six peer groups analyzed. On the horizontal axis, the Alpha decile over the estimation period is represented, and on the vertical axis the average annual Alpha of a decile's funds over the performance period is depicted.

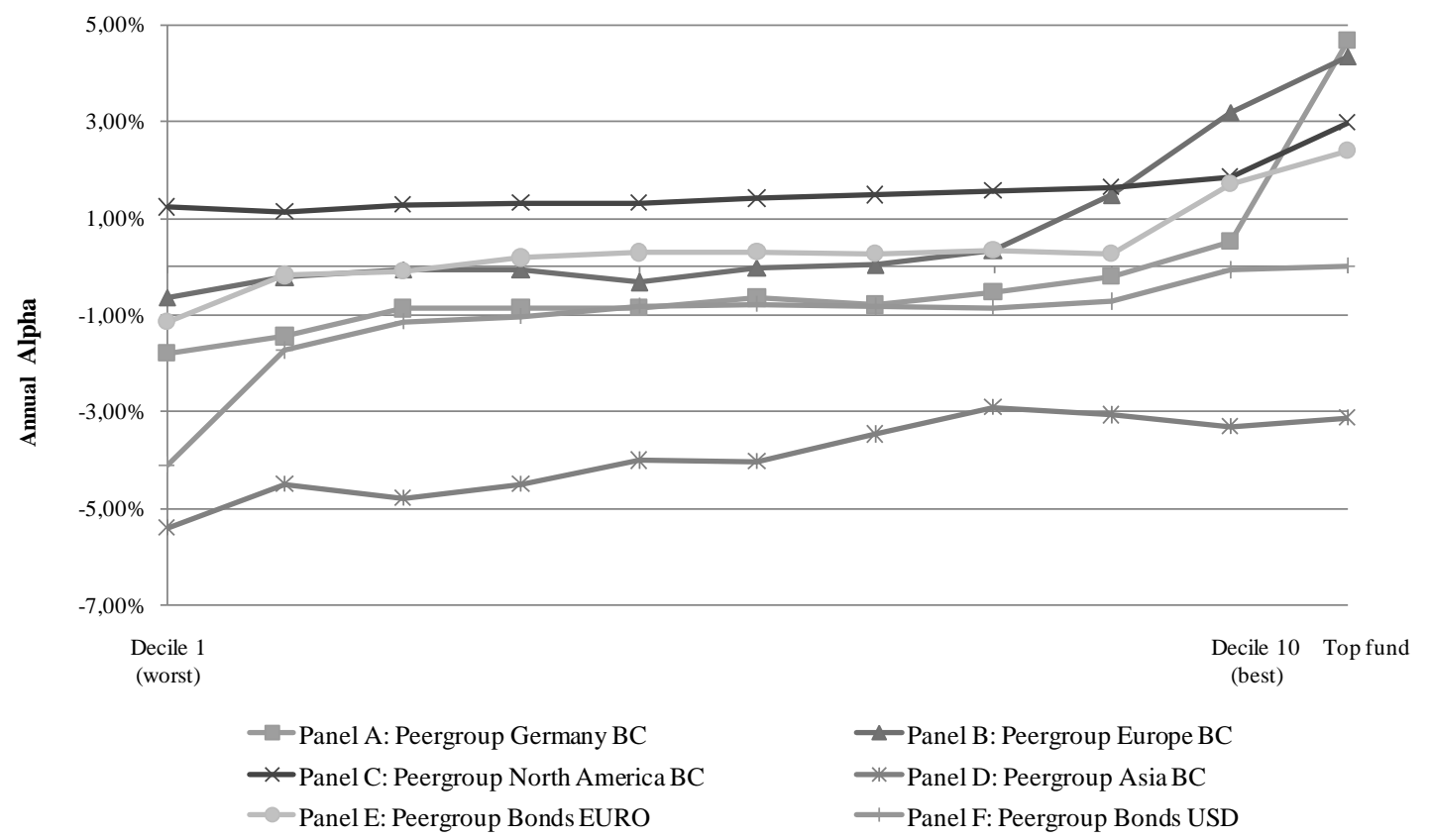

The results presented in Table 5 support hypothesis 1 . Sophisticated investors pursuing an Alpha chasing strategy perform better than unsophisticated investors who randomly select a fund. This outperformance is proven by all three performance indicators employed. The sophisticated investor realizes an Alpha of $1.89 \%$ p.a. over all peer groups, whereas the unsophisticated investor generates an Alpha of $-0.97 \%$ p.a.. The difference is statistically significant at the $1 \%$-level. Additionally, on a peer group level the sophisticated investor always outperforms the unsophisticated one. The differences in Alphas are statistically significant in 5 of 6 cases. The results remain qualitatively unchanged if we account for potential autocorrelation in Alphas.

Measured in returns, the sophisticated investor outperforms its unsophisticated counterpart by $2.59 \%$ p.a.. As before, in every peer group there is a positive return difference between the sophisticated Alpha strategy and an unsophisticated fund selection strategy. Even if we exclude the peer group Stocks Germany Blue Chips for which the return seems extraordinarily high for the Alpha strategy, the average difference over the remaining five peer groups is still $1.38 \%$ and strongly significant. However, note that for three peer groups the outperformance of the Alpha strategy is less than one percentage point per year and statistically not significant. 


\section{Table 5: Performance of Sphisticated vs. Unsophisticated Investors}

The table presents results for hypothesis 1. The performance is measured as mean Alpha performance p.a., mean one-year buy-and-hold returns p.a. and outperformance ratio. The sophisticated investor selects the fund with the highest Alpha performance in the one-year period prior to the investment date and then holds on to the investment decision for one year. The unsophisticated investor achieves the average performance of all funds in a respective peer group in the performance period. Both investors are not subject to any institutional boundaries. $*, * *, * * *$ denote significance at the $10 \%, 5 \%$ and $1 \%$-level; "n.s." indicates that the difference is insignificant.

\begin{tabular}{|c|c|c|c|c|c|c|c|c|}
\hline Peer group & weigth & $\begin{array}{l}\text { Sophisticated } \\
\text { investor }\end{array}$ & $\begin{array}{c}\text { Un- } \\
\text { sophisticated } \\
\text { investor } \\
\end{array}$ & Difference & $\begin{array}{c}\text { t-test } \\
\text { (one } \\
\text { tailed) } \\
\end{array}$ & $\begin{array}{c}\text { t-test } \\
\text { (Newey- } \\
\text { West } \\
\end{array}$ & $\begin{array}{c}\text { Benchmark } \\
\text { index }\end{array}$ & $\begin{array}{c}\text { Difference } \\
\text { sophisticated }\end{array}$ \\
\hline & & \multicolumn{7}{|c|}{ Alpha Performance p.a. (mean) } \\
\hline Stocks Germany Blue Chips & $16.7 \%$ & $4.67 \%$ & $-1.22 \%$ & $5.89 \%$ & $* * *$ & **** & & \\
\hline Stocks Europe Blue Chips & $16.7 \%$ & $4.36 \%$ & $-0.92 \%$ & $5.28 \%$ & $* * *$ & $* *$ & & \\
\hline Stocks North America Blue Chips & $16.7 \%$ & $2.99 \%$ & $1.59 \%$ & $1.40 \%$ & $*$ & n.s. & & \\
\hline Stocks Asia Blue Chips & $16.7 \%$ & $-3.12 \%$ & $-3.68 \%$ & $0.56 \%$ & n.s. & n.s. & & \\
\hline Bonds EURO & $16.7 \%$ & $2.40 \%$ & $0.03 \%$ & $2.36 \%$ & $* * *$ & $* * *$ & & \\
\hline Bonds USD & $16.7 \%$ & $0.02 \%$ & $-1.61 \%$ & $1.64 \%$ & $* * *$ & $* * *$ & & \\
\hline \multirow[t]{2}{*}{ Overall } & $100.0 \%$ & $1.89 \%$ & $-0.97 \%$ & $2.85 \%$ & $* * *$ & $* * *$ & & \\
\hline & & \multicolumn{7}{|c|}{ Absolute Return p.a. (mean) } \\
\hline Stocks Germany Blue Chips & $16.7 \%$ & $13.66 \%$ & $5.06 \%$ & $8.60 \%$ & $* * *$ & **** & $8.83 \%$ & $4.82 \%$ \\
\hline Stocks Europe Blue Chips & $16.7 \%$ & $10.10 \%$ & $6.44 \%$ & $3.66 \%$ & $* * *$ & n.s. & $11.83 \%$ & $-1.72 \%$ \\
\hline Stocks North America Blue Chips & $16.7 \%$ & $7.49 \%$ & $7.08 \%$ & $0.40 \%$ & n.s. & n.s. & $10.52 \%$ & $-3.04 \%$ \\
\hline Stocks Asia Blue Chips & $16.7 \%$ & $3.92 \%$ & $3.19 \%$ & $0.73 \%$ & n.s. & n.s. & $5.58 \%$ & $-1.66 \%$ \\
\hline Bonds EURO & $16.7 \%$ & $6.31 \%$ & $4.45 \%$ & $1.86 \%$ & $* * *$ & $* * *$ & $6.24 \%$ & $0.08 \%$ \\
\hline Bonds USD & $16.7 \%$ & $4.78 \%$ & $4.52 \%$ & $0.27 \%$ & n.s. & n.s. & $6.26 \%$ & $-1.47 \%$ \\
\hline \multirow[t]{2}{*}{ Overall } & $100.0 \%$ & $7.71 \%$ & $5.12 \%$ & $2.59 \%$ & $* * *$ & $* * *$ & $8.21 \%$ & $-0.50 \%$ \\
\hline & & \multicolumn{7}{|c|}{ Hit Ratio (\% of decisions with return higher than benchmark) } \\
\hline Stocks Germany Blue Chips & $16.7 \%$ & $63.9 \%$ & $40.2 \%$ & $23.7 \%$ & & & & \\
\hline Stocks Europe Blue Chips & $16.7 \%$ & $49.3 \%$ & $33.3 \%$ & $16.0 \%$ & & & & \\
\hline Stocks North America Blue Chips & $16.7 \%$ & $44.8 \%$ & $11.5 \%$ & $33.3 \%$ & & & & \\
\hline Stocks Asia Blue Chips & $16.7 \%$ & $43.2 \%$ & $28.9 \%$ & $14.3 \%$ & & & & \\
\hline Bonds EURO & $16.7 \%$ & $54.2 \%$ & $34.1 \%$ & $20.0 \%$ & & & & \\
\hline Bonds USD & $16.7 \%$ & $34.0 \%$ & $39.9 \%$ & $-5.9 \%$ & & & & \\
\hline Overall & $100.0 \%$ & $48.2 \%$ & $31.3 \%$ & $16.9 \%$ & & & & \\
\hline
\end{tabular}

In line with most other studies on mutual fund performance (e.g. Malkiel (2003)) even the sophisticated investor is generally unable to outperform the respective benchmark indices. Only for the peer group Stocks Germany Blue Chips, the sophisticated investor generates a positive excess return. Additionally for Bonds Euro, we find a slightly positive excess return. In all other peer groups the Alpha strategy loses at least $1 \%$ per annum compared to respective benchmark index. The underperformance is particularly pronounced for Stocks North America Blue Chips.

As already pointed out, our database does not contain any further information on terminated funds which could potentially bias our results. However, top funds selected by the Alpha strategy are never terminated during the performance period; hence we do not have to make any assumptions about the behavior of a sophisticated investor in the event of a fund termination. However, as performance measures are not computed if a fund was terminated in the course of that year, it is probable that we slightly overestimate the returns to the unsophisticated investor. This is because terminated 
funds usually underperform prior to their termination as the migration matrix in Table 6 for the peer group Stocks Europe Blue Chips proves (column 'deleted funds').

\section{Table 6: Migration Matrix}

The table presents the migration matrix for the peer group stocks Europe Blue Chips. On the vertical axis (Old Decile) the table represents a fund's Alpha decile over the estimation period, whereas on the horizontal axis (New decile) the table depicts this fund's Alpha decile over the performance period. "New funds" represents funds that were set up during the estimation period, whereas "deleted funds" summarizes funds that were terminated before the end of the performance period. The percentage values refer to row totals.

\begin{tabular}{|c|c|c|c|c|c|c|c|c|c|c|c|c|}
\hline & & \multicolumn{11}{|c|}{ New decile } \\
\hline & & 0.0 & 0.1 & 0.2 & 0.3 & 0.4 & 0.5 & 0.6 & 0.7 & 0.8 & 0.9 & $\begin{array}{l}\text { Deleted } \\
\text { funds }\end{array}$ \\
\hline \multirow{11}{*}{$\begin{array}{c}\text { Old } \\
\text { Decile }\end{array}$} & 0.0 & $23.4 \%$ & $11.6 \%$ & $9.1 \%$ & $7.7 \%$ & $7.0 \%$ & $6.9 \%$ & $6.1 \%$ & $6.4 \%$ & $7.5 \%$ & $14.3 \%$ & $23.5 \%$ \\
\hline & 0.1 & $13.4 \%$ & $13.1 \%$ & $10.5 \%$ & $11.0 \%$ & $10.1 \%$ & $9.1 \%$ & $8.8 \%$ & $8.4 \%$ & $8.1 \%$ & $7.4 \%$ & $12.8 \%$ \\
\hline & 0.2 & $9.5 \%$ & $11.1 \%$ & $11.5 \%$ & $11.4 \%$ & $10.4 \%$ & $10.8 \%$ & $10.5 \%$ & $9.7 \%$ & $9.0 \%$ & $6.0 \%$ & $10.8 \%$ \\
\hline & 0.3 & $7.8 \%$ & $10.6 \%$ & $11.3 \%$ & $11.3 \%$ & $11.1 \%$ & $12.8 \%$ & $11.4 \%$ & $9.8 \%$ & $8.6 \%$ & $5.3 \%$ & $11.8 \%$ \\
\hline & 0.4 & $7.4 \%$ & $9.8 \%$ & $11.9 \%$ & $11.8 \%$ & $12.9 \%$ & $12.9 \%$ & $11.5 \%$ & $9.8 \%$ & $7.6 \%$ & $4.4 \%$ & $8.8 \%$ \\
\hline & 0.5 & $6.1 \%$ & $9.6 \%$ & $11.4 \%$ & $12.4 \%$ & $13.9 \%$ & $12.1 \%$ & $11.2 \%$ & $10.6 \%$ & $8.0 \%$ & $4.7 \%$ & $7.3 \%$ \\
\hline & 0.6 & $6.0 \%$ & $10.2 \%$ & $11.2 \%$ & $11.4 \%$ & $11.7 \%$ & $11.5 \%$ & $11.7 \%$ & $11.2 \%$ & $9.1 \%$ & $6.0 \%$ & $5.8 \%$ \\
\hline & 0.7 & $7.3 \%$ & $9.2 \%$ & $10.4 \%$ & $10.6 \%$ & $10.7 \%$ & $10.7 \%$ & $11.0 \%$ & $11.2 \%$ & $10.8 \%$ & $8.2 \%$ & $7.0 \%$ \\
\hline & 0.8 & $7.8 \%$ & $7.8 \%$ & $8.0 \%$ & $8.6 \%$ & $8.3 \%$ & $8.7 \%$ & $10.5 \%$ & $11.8 \%$ & $15.2 \%$ & $13.1 \%$ & $6.3 \%$ \\
\hline & 0.9 & $11.6 \%$ & $7.3 \%$ & $5.7 \%$ & $5.6 \%$ & $5.6 \%$ & $6.2 \%$ & $7.0 \%$ & $9.1 \%$ & $14.2 \%$ & $27.7 \%$ & $5.9 \%$ \\
\hline & $\begin{array}{l}\text { new } \\
\text { funds }\end{array}$ & $10.4 \%$ & $9.7 \%$ & $9.6 \%$ & $8.9 \%$ & $8.9 \%$ & $9.3 \%$ & $10.1 \%$ & $10.6 \%$ & $10.6 \%$ & $11.9 \%$ & \\
\hline
\end{tabular}

Summarizing the results concerning the first hypothesis, we find that for German investors, it is costly not to be sophisticated. A sophisticated investor outperforms an unsophisticated one by $2.85 \%$ per annum measured in returns.

In the next step, this paper tests hypothesis 2, and checks whether institutional boundaries are actually costly to investors. For sophisticated investors, the results essentially support the hypothesis that institutional boundaries are costly, whereas for unsophisticated investors no effect is discernible. Table 7 presents a comparison between investors that are subject to institutional boundaries and those that are not. We allow investors to be either sophisticated (part 1 of Table 7) or unsophisticated (part 2). To provide the reader with a detailed overview, we additionally report the results for each investment company separately.

Regarding the Alpha performance, unconstrained investors pursuing an Alpha chasing strategy have to bear non-trivial costs once they are institutionally bounded. In fact, in absence of institutional boundaries a sophisticated investor realizes on average a significantly (1\%-level) higher Alpha than the average institutionally bounded investor does ( $1.89 \%$ p.a. vs. $0.30 \%$ p.a.). For all peer groups there exists a positive difference, 
though for three peer groups only a small and statistically insignificant effect can be observed. This result is confirmed by considering one year buy-and-hold returns. The unconstrained investor generates an excess return of $1.08 \%$ p.a. on average which is statistically significant at the $1 \%$-level. If success is measured in outperformance ratios, then institutionally bounded investors underperform in every peer group.

The results for sophisticated but institutionally bounded investors vary strongly from investment company to investment company. The Alpha spread between the best and the worst investment company is - expressed as an average of all peer groups $-2.57 \%$ p.a. and the corresponding returns difference amounts to $2.69 \%$ p.a.. Hence, it becomes obvious that some investment companies perform better than others, though there is no stable pattern across the various peer groups. Consequently, the absence of institutional boundaries induces an outperformance even in comparison to the best of the investment companies, although the advantage expressed on Alphas decreases to only $0.27 \%$ p.a. calculated as average of the different peer groups. Additionally, it is interesting to note that on a peer group level, the sophisticated and institutionally bounded investor does not always outperform all other sophisticated but constrained investors.

For unsophisticated investors, no major benefit of an absence of institutional boundaries can be detected. As Table 8 shows, institutionally bounded investors have only a slight average disadvantage of $0.09 \%$ p.a. measured in Alpha. In contrast, when performance is measured in one year buy-and-hold returns or in outperformance ratios, a slight performance advantage for the institutionally bounded investor is discernible. For unsophisticated investors institutional boundaries seem to have no economically significant impact. Again, even for unsophisticated investors, a larger spread between the worst and the best investment company both in Alpha (1.56\% p.a.) and in return ( $1.71 \%$ p.a.) can be observed. As far as hypothesis 2 is concerned, there is no indication that the absence of institutional boundaries is performance enhancing for unsophisticated investors. 


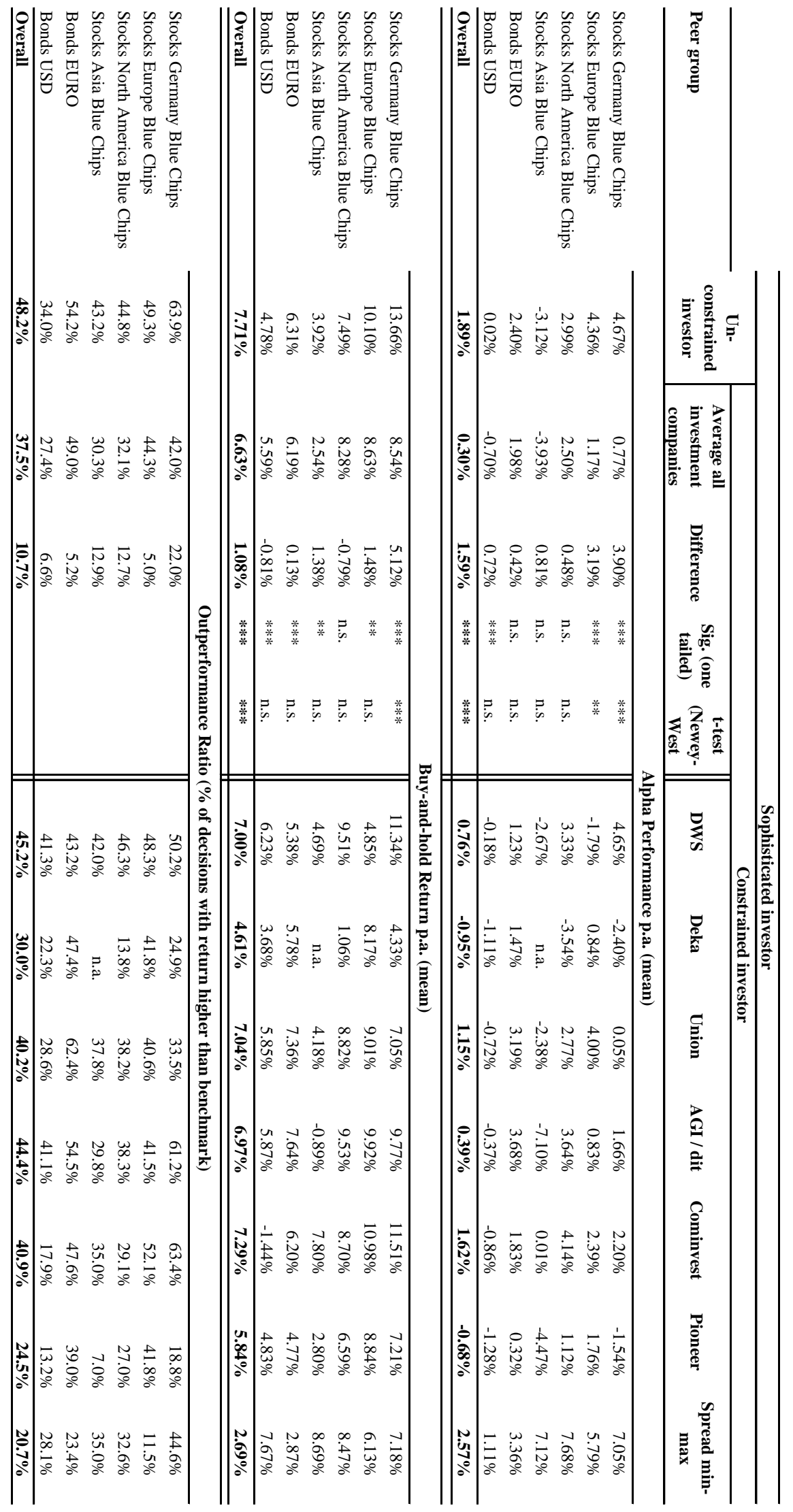

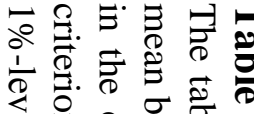
¿.

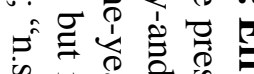

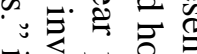

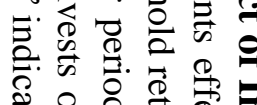

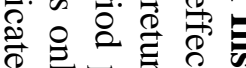

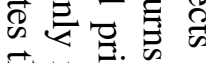

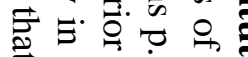
居志 눙휴 龸 ๑ $\approx$ ఠ ठ

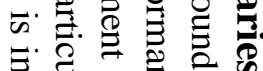

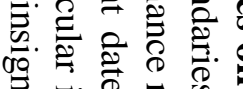

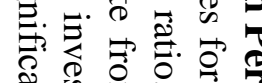

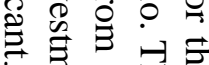

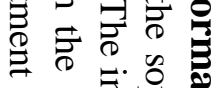
$\delta$ छ 总 䒠 怘

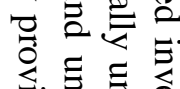
․․ㅇ.

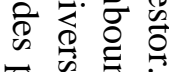
एक

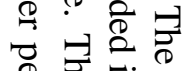
Ф 哭 ㄹ. * 웅 * *茟官官 จे

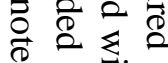
‥ ㅋ.

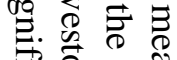
규:

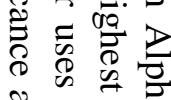
$\approx=2$

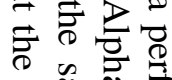
유유. 넹ㅇㅇ วิ?

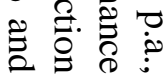





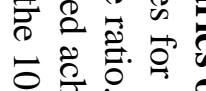

की 设客宁

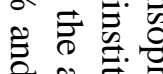

艺声.

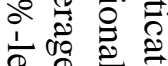

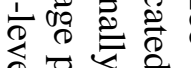

용

융 छ

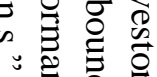

플

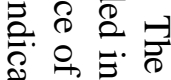

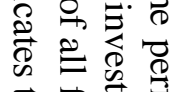

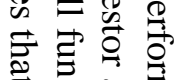

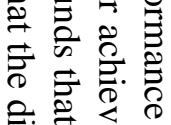

危产市通

के

ठ․ㅠ.

ज.

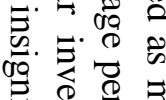

宽.

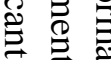

ठํㅠ

串

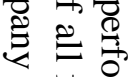

灾面

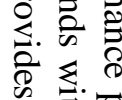

家 


\section{Table 8: Comparison of Costs of Selection Strategy and Institutional Boundaries}

The table presents a cross-comparison of Alpha performance p.a. and buy-and-hold returns p.a. depending selection strategy applied and the presence of. institutional boundaries. The sophisticated investor follows an Alpha chasing strategy, whereas for the unsophisticated investor it is assumed that he or she invests into the average fund. Both investors may be institutionally bounded or unbounded. An unbounded investor can freely choose from the whole fund universe. An institutionally bounded investor in contrast can only invest into funds of a particular investment company. The figures presented here are averages over all six investment companies considered.

Panel A: Alpha Performance p.a. (mean)

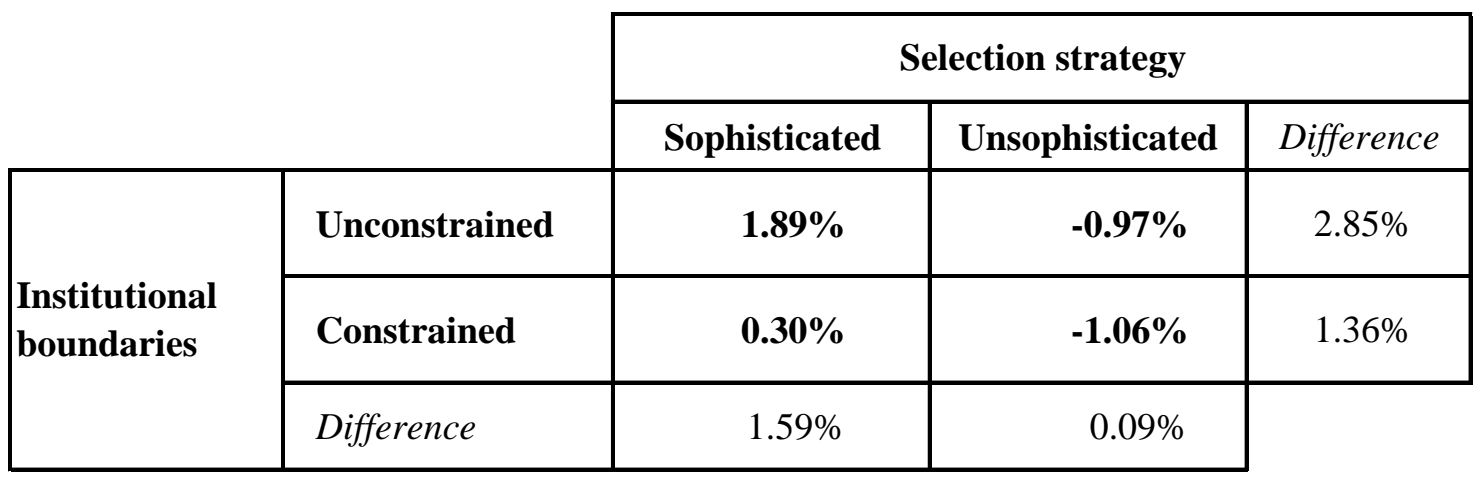

Panel B: Buy-and-hold Return p.a. (mean)

\begin{tabular}{|l|l|r|r|c|}
\cline { 3 - 5 } \multicolumn{2}{c|}{} & \multicolumn{3}{c|}{ Selection strategy } \\
\cline { 3 - 5 } \multicolumn{2}{c|}{} & Sophisticated & Unsophisticated & Difference \\
\hline \multirow{3}{*}{$\begin{array}{l}\text { Institutional } \\
\text { boundaries }\end{array}$} & Unconstrained & $\mathbf{7 . 7 1 \%}$ & $\mathbf{5 . 1 2 \%}$ & $2.59 \%$ \\
\cline { 2 - 5 } & Constrained & $\mathbf{6 . 6 3 \%}$ & $\mathbf{5 . 1 7 \%}$ & $1.46 \%$ \\
\cline { 2 - 5 } & Difference & $1.08 \%$ & $-0.04 \%$ & \\
\hline
\end{tabular}

The results obtained so far permit us to judge what effect is more costly to the investor: being institutionally bounded or unsophisticated, and also the effect of being both. Table 8 summarizes the crucial numbers from the previous tables.

Not chasing Alphas, i.e. being unsophisticated, has got a stronger negative impact than being institutionally bounded. Whereas the Alpha difference between sophisticated and unsophisticated investors who are subject to institutional boundaries is $1.6 \%$ p.a., an elimination of institutional boundaries further enhances the Alpha performance by $1.4 \%$ p.a.. For unsophisticated investors, there are hardly any performance effects regardless of the presence of institutional boundaries. Consequently, the quality of the fund selection process is more important than the available fund universe. However, once a 
high quality fund selection process has been established, additional performance can be achieved by elimination of institutional boundaries.

Finally, this paper focuses on the third hypothesis, which claims that using a criterion that combines both the Alpha performance and the ability of managers to generate repeatedly superior performance improves the fund selection for sophisticated investors. Table 9 presents results for the selection strategy based on the new APR and contrasts it with the previously deployed Alpha strategy. The results generally support the hypothesis. A sophisticated unconstrained investor who selects funds on the basis of the APR generates an Alpha that is $0.89 \%$ p.a. higher than the one an Alpha-chaser would attain. This outperformance manifests if we draw on one year buy-and-hold returns or outperformance ratios. The return is $1.17 \%$ p.a. and the outperformance ratio $7.3 \%$ higher than for an Alpha-chaser. The effects on the Alpha and return are both statistically significant at the $1 \%$-level and at the $5 \%$-level once we take potential autocorrelation into account. Also on a disaggregate level, the APR outperforms the Alpha strategy with the only exception being the peer group Stocks Germany Blue Chips. However, the outperformance of the APR is only significant in 3 out of 6 peer groups when looking at Alphas and in 4 out 6 when turning to returns. The number of significant peer groups further decreases once we control for potential autocorrelation. Note also that the strategy based on the APR on average outperforms the respective benchmark indices.

Applying the APR to sophisticated but constrained investors affects the performance measures negatively. Alphas and the outperformance ratio indicate that using the APR to institutionally bounded and sophisticated investors underperforms a fund selection strategy based on Jensen's Alpha whereas no effect can be documented for one year buy-and-hold returns. We might speculate that the APR does not work for institutionally bound investors, since it may also be possible that investment companies promote their one or two star funds per peer group that are not necessarily selected by the APR. Evidence from the United States shows that investment companies do indeed promote and probably even cross-subsidize their star funds (Gaspar et al. (2006)). 


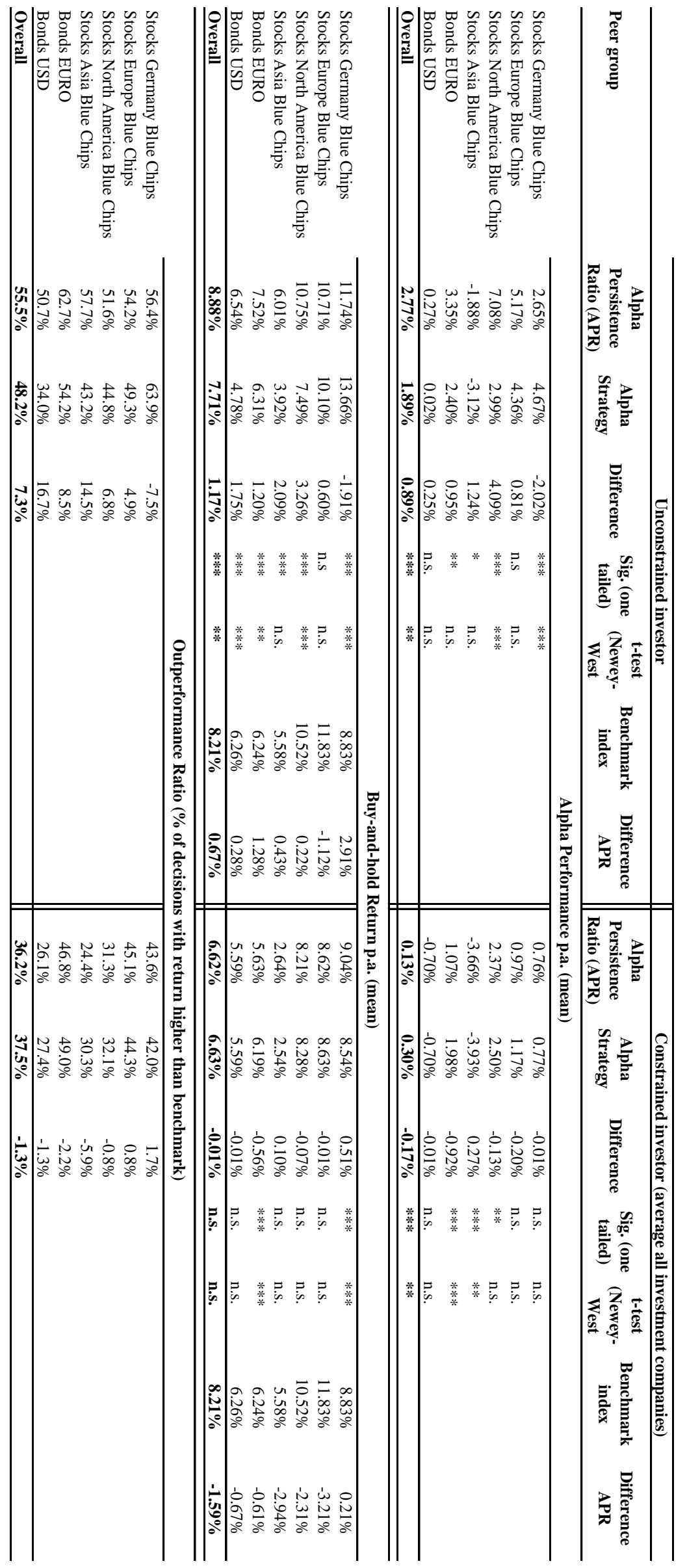

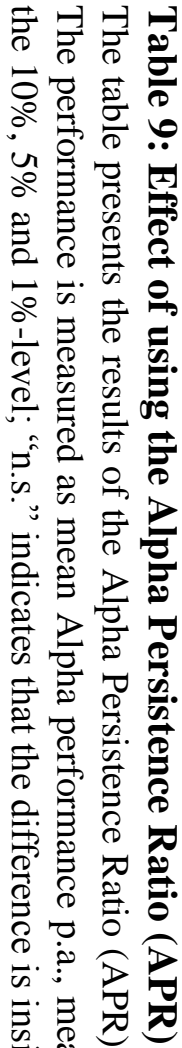

品㐨

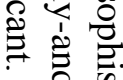

홍

을

ह

芯

i

芑䒕.

䒿 $\stackrel{\varrho}{\circ}$

兽泀.

突

홍.

$*$

*

*

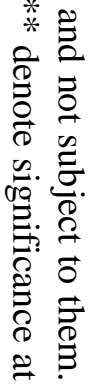


In hypothesis 3 this paper has proposed to use a new measure called APR to further enhance the returns to a sophisticated and non-institutionally bounded investor. Results haven proven that the APR is capable of fulfilling this task. However, this measure does not seem beneficial to an institutionally bounded investor who can only choose from a limited number of funds.

\section{Robustness Tests}

For checking the validity of the results regarding the three hypotheses, we performed several robustness checks.

First, we changed the number of selected funds for the sophisticated investor. Instead of assuming that the investor invests into the fund with the best past year Alpha performance, we compute an equally weighted portfolio consisting of funds in the $10^{\text {th }}$ decile. After recalculating the different peer groups, it turned out that results remain qualitatively unchanged. It still pays to pursue a sophisticated strategy, and if such a strategy is applied, it is also still beneficial not to be institutionally bound.

Although studies like Kosowski et al. (2006) report no qualitative differences between alternative Alpha estimation techniques, we nevertheless tested for the peer group "North America Blue Chips" whether results changed if a three factor Fama-French model (Fama and French (1993)) was employed to calculate the Alphas. In comparison to the simple one-factor model results stay qualitatively unchanged. In fact, it seems that a three factor model might even enhance the fund selection as the return for the particular peer group tested was found to be higher.

The results of this study could be further driven by two additional factors. The first is that the funds selected could simply exhibit a higher beta, which would explain the excess return measured and the second is that we simply selected funds with higher loads. We addressed both issues in unreported tests and found that neither the beta for the funds selected was statistically different from the average beta nor was the average load.

As mentioned by Lu (1999), results of fund selection strategies may be biased by autocorrelation. To control this bias in each of the tables, we report not only t-tests, but also t-statistics adjusted for autocorrelation using the Newey-West covariance matrix. To apply it, it is necessary to determine the optimal lag length to be used in the NeweyWest correction. To do so, the Akaike information criteria, Schwarz Information Criteria and Hannan-Quinn Information Criteria are used. The lag length preferred by 
the majority of these tests is three. This lag length is used as input for the Newey-West correction. For some peer groups and some strategies, the statistical significance reported by one-tailed t-tests decreases, however the grand averages over all peer groups remain unchanged. Thus we conclude that all major results remain unchanged if using different methods of Alpha estimation or significance testing.

\section{Conclusion}

This study contributes to the growing body of literature that aims at measuring the costs of individual investor's investment mistakes. In contrast to earlier studies focusing on home bias and non-participation (Calvet et al. (2007)), this study focuses on the fund selection process and aims at assessing the costs not chasing Alphas and institutional boundaries. Therefore, this paper's empirical analysis is based on data of actively managed mutual funds that are available to German investors. We employ a survivorship bias free sample of almost 3,000 mutual funds and document non-trivial costs of not chasing Alphas and institutional boundaries.

We focus on the two major reasons described by Gruber (1996) for which investors may abstain from chasing past Alpha. An investor could be unsophisticated, i.e. not chasing past Alpha performance, or institutionally bound, i.e. in our terms constrained to the funds of a certain investment company. In total, the costs of being simultaneously unsophisticated and institutionally bound sum up to $2.85 \%$ p.a. expressed in Alpha. Further deeper-analysis of the results reveals that there is always a cost associated with being unsophisticated, whereas the costs of institutional boundaries are only existent for sophisticated investors. For the latter, abolishing institutional boundaries results in an increase of Alpha performance of $1.6 \%$ p.a., whereas for unsophisticated investors we do not find any differences.

Furthermore, we introduce a new criterion for fund selection. This new measure integrates not only fund managers' current Alpha performance but also their ability to repeatedly achieve superior results in comparison to their peers. The new measure which we call Alpha Persistence Ratio (APR) is able to further improve the fund selection of a sophisticated investor resulting in an Alpha outperformance in comparison to a pure Alpha chasing strategy of $0.89 \%$ p.a..

This study is hence another example that suboptimal investment decisions of households result in non-trivial costs. If the investors pursue an Alpha chasing strategy and consider all mutual funds available then these costs may diminish. In fact, this paper 
suggests that financial education could actually be a remedy to the problem just as Campbell (2006) notes. As it seems hardly possible to educate all investors, financial advice could add value, by introducing a sensible fund selection strategy.

However, even if doing so, there still exists the problem of institutional boundaries due to the described affiliation of banks and investment companies. Thus, we also conclude that banks should seriously consider introducing an open architecture, i.e. offering all available mutual funds. If not doing so, regulators should take action to force banks as these boundaries have significant influence on economic welfare.

The limitations of this study can be considered as potential for further research in this area as well. Since this study is only based on data on the German mutual fund market, it may also be interesting to have evidence from other countries on the costs of institutional boundaries and unsophisticated fund selection strategies. We would expect that in less bank dependent financial systems, the costs of institutional boundaries are less pronounced since competition among investment companies may positively affect performance of the dominant players.

Additionally, it would be interesting to empirically investigate into the question why individual investors abstain from chasing past performance. It might be that investors are truly unsophisticated and are not aware of the benefits of chasing past performance. However, it might also be possible that investors are aware of the benefits of performance chasing but are subject to institutional boundaries that hamper them from actually chasing past performance. We suggest including mutual fund flows for such an analysis.

Although most other studies as well as our robustness checks for the peer group "North America Blue Chips" have not reported qualitatively different results whether Jensen's Alpha, 3-factor Alpha or 4-factor Alphas were used, it would still be interesting to see if the APR could be further enhanced by using these alternative Alpha estimation techniques. 


\section{References}

BARBER, B. M. and ODEAN, T. (2000): "Trading Is Hazardous to Your Wealth: The Common Stock Investment Performance of Individual Investors", in: Journal of Finance, Vol. 55, No. 2, pp. 773-806.

BER, S., KEMPF, A. and RUENZI, S. (2007): "Determinanten Der Mittelzuflüsse Bei Deutschen Aktienfonds", in: Schmalenbachs Zeitschrift für betriebswirtschaftliche Forschung, Vol. 59, No. 2, pp. 35-60

BLISS, R. T. and POTTER, M. E. (2002): "Mutual Fund Managers: Does Gender Matter?" in: Journal of Business \& Economic Studies, Vol. 8, No. 1, pp. 1-15.

BVI (2007): "Gesamtstatistik", September 2007, Frankfurt am Main.

CALVET, L. E., CAMPBELL, J. Y. and SODINI, P. (2007): "Down or Out: Assessing the Welfare Costs of Household Investment Mistakes", in: Journal of Political Economy, Vol. 115, No. 5, pp. 707-747.

CAMPBELL, J. Y. (2006): "Household Finance", in: Journal of Finance, Vol. 61, No. 4, pp. 1553-1604.

CARHART, M. M. (1997): "On Persistence in Mutual Fund Performance", in: Journal of Finance, Vol. 52, No. 1, pp. 57-82.

CARHART, M. M., CARPENTER, J. N., LYNCH, A. W. and MUSTO, D. K. (2002): "Mutual Fund Survivorship", in: Review of Financial Studies, Vol. 15, No. 5, pp. 1439-1464.

CHAN, L. K. C., HSIU-LANG, C. and LAKONISHOK, J. (2002): "On Mutual Fund Investment Styles", in: Review of Financial Studies, Vol. 15, No. 5, pp. 14071437.

CREMERS, K. J. M. and PETAJISTO, A. (2007): "How Active Is Your Fund Manager? A New Measure That Predicts Performance", Working Paper, AFA 2007 Chicago Meetings.

DABBANK (2004): "Faszination Wertpapier: Fakten Und Hintergründe Zum Anlegerverhalten in Deutschland", Munich.

ELTON, E. J., GRUBER, M. J. and BLAKE, C. R. (1996): "The Persistence of RiskAdjusted Mutual Fund Performance", in: Journal of Business, Vol. 69, No. 2, pp. 133-157.

ELTON, E. J., GRUBER, M. J. and BLAKE, C. R. (2001): "A First Look at the Accuracy of the Crsp Mutual Fund Database and a Comparison of the Crsp and Morningstar Mutual Fund Databases", in: Journal of Finance, Vol. 56, No. 6, pp. 2415-2430.

FAMA, E. F. and FRENCH, K. R. (1993): "Common Risk Factors in the Returns on Stocks and Bonds", in: Journal of Financial Economics, Vol. 33, No. 1, pp. 3-56.

FRINO, A. and GALLAGHER, D. R. (2001): "Tracking S\&P 500 Index Funds", in: Journal of Portfolio Management, Vol. 28, No. 1, pp. 44-55.

GASPAR, J.-M., MASSA, M. and MATOS, P. (2006): "Favoritism in Mutual Fund Families? Evidence on Strategic Cross-Fund Subsidization", in: Journal of Finance, Vol. 61, No. 1, pp. 73-104. 
GRINBLATT, M. and TITMAN, S. (1992): "The Persistence of Mutual Fund Performance", in: Journal of Finance, Vol. 47, No. 5, pp. 1977-1984.

GRUBER, M. J. (1996): "Another Puzzle: The Growth in Actively Managed Mutual Funds", in: Journal of Finance, Vol. 51, No. 3, pp. 783-810.

GUISO, L., HALIASSOS, M. and JAPPELLI, T. (2003): "Household Stockholding in Europe: Where Do We Stand and Where Do We Go?" in: Economic Policy, Vol. 18 , No. 36, pp. 125-170.

HENDRICKS, D., PATEL, J. and ZECKHAUSER, R. (1993): "Hot Hands in Mutual Funds: Short-Run Persistence of Relative Performance, 1974-1988", in: Journal of Finance, Vol. 48, No. 1, pp. 93-130.

HSIU-LANG, C., JEGADEESH, N. and WERMERS, R. (2000): "The Value of Active Mutual Fund Management: An Examination of the Stockholdings and Trades of Fund Managers", in: Journal of Financial \& Quantitative Analysis, Vol. 35, No. 3, pp. 343-368.

JANSEN, C., FISCHER, R. and HACKETHAL, A. (2008): "The Influence of Financial Advice on the Asset Allocation of Individual Investors", Working Paper, European Business School.

JENSEN, M. C. (1968): "The Performance of Mutual Funds in the Period 1945-1964", in: Journal of Finance, Vol. 23, No. 2, pp. 389-416.

KESWANI, A. and STOLIN, D. (2008): "Which Money Is Smart? Mutual Fund Buys and Sells of Individual and Institutional Investors", in: Journal of Finance, Vol. 63, No. 1, pp. 85-118.

KOSOWSKI, R., TIMMERMANN, A., WERMERS, R. and WHITE, H. A. L. (2006): "Can Mutual Fund "Stars" Really Pick Stocks? New Evidence from a Bootstrap Analysis", in: Journal of Finance, Vol. 61, No. 6, pp. 2551-2595.

LEWIS, K. K. (1999): "Trying to Explain Home Bias in Equities and Consumption", in: Journal of Economic Literature, Vol. 37, No. 2, pp. 571-608.

LU, Z. (1999): "Is Money Smart? A Study of Mutual Fund Investors' Fund Selection Ability", in: Journal of Finance, Vol. 54, No. 3, pp. 901-933.

MALKIEL, B. G. (2003): "Passive Investment Strategies and Efficient Markets", in: European Financial Management, Vol. 9, No. 1, pp. 1-10.

NIESSEN, A. and RUENZI, S. (2006): "Sex Matters: Gender Differs in a Professional Setting", CFR Working Paper.

OECD (2005): "Improving Financial Literacy: Analysis of Issues and Politics", Paris, France.

OTTAVIANI, M. (2000): "The Economics of Advice", Working Paper, London Business School.

SIRRI, E. R. and TUFANO, P. (1998): "Costly Search and Mutual Fund Flows", in: Journal of Finance, Vol. 53, No. 5, pp. 1589-1622.

WERMERS, R. (2000): "Mutual Fund Performance: An Empirical Decomposition into Stock-Picking Talent, Style", in: Journal of Finance, Vol. 55, No. 4, pp. 16551695.

ZHAO, X. (2005): "The Role of Brokers and Financial Advisors Behind Investments into Load Funds", Working Paper. 